\title{
Ex situ conservation storage potential of Saxifraga cernua (Saxifragaceae) bulbils from alpine species
}

\author{
Elinor Breman ${ }^{1}$ (D) Jacqueline Détraz-Méroz ${ }^{2} \cdot$ Janet Terry $^{1} \cdot$ Catherine Lambelet $^{2}$
}

Received: 4 December 2018 / Accepted: 2 August 2019/Published online: 5 September 2019

(C) The Author(s) 2019

\begin{abstract}
In high latitude and alpine environments many plants show an increase in viviparous reproduction in response to harsh environmental conditions. Low or no seed set means that ex situ conservation in the form of seed banking is not a conservation option for such species. We investigated the potential for bulbils to be stored ex situ in seed banks using traditional storage methods (drying and freezing at $-20^{\circ} \mathrm{C}$ ) and cryopreservation (drying and freezing at $-180^{\circ} \mathrm{C}$ ) as a means of ensuring the long-term conservation of such species. In addition, the impact of drying bulbils to $15 \% \mathrm{eRH}$ or maintaining initial humidity $(60 \% \mathrm{eRH})$ was investigated. The study was based on bulbils of the drooping or nodding saxifrage (Saxifraga cernua) collected in Bellalui (commune d'Icogne, Switzerland) at an altitude of 2200 m.a.s.l. Our findings suggest that conservation under traditional seed banking methods or by cryopreservation is a viable option for species producing small $(<2 \mathrm{~mm})$ bulbils. This provides new hope for conserving high altitude or latitude plants producing bulbils.
\end{abstract}

Keywords Bulbils $\cdot$ Cryopreservation $\cdot$ Germination $\cdot$ Humidity $\cdot$ Saxifraga cernua $\cdot$ Seed bank $\cdot$ Viability

\section{Introduction}

The European Alps form an arc stretching $1200 \mathrm{~km}$ from the Mediterranean coast to the Vienna Basin and form a regional center of plant diversity. The vascular plant flora of the Alps comprises 4485 taxa, of which 2433 taxa are present in subalpine to nival belts (Aeschimann et al. 2011). The occurrence of high levels of endemism at altitude, of high species richness and of the services provided by alpine ecosystem has made the Alps one of the most important regions for plant life in Europe. However, high mountains and alpine ecosystems are also the most threatened ecosystems in Europe as a result of human pressure, transformative land uses and global warming (Gottfried et al. 2012; Pauli et al. 2012).

To address the threats facing the alpine flora a regional network covering the European Alps has been developed to

Elinor Breman

e.breman@kew.org

1 Royal Botanic Gardens, Kew, Millennium Seed Bank, Wakehurst, Ardingly, West Sussex RH17 6TN, UK

2 Conservatoire et Jardin botaniques (CJB), Unité Flores, Conservation \& Systèmes d'Information, Ch. de l'Impératrice 1, case postale 60 , 1292 Chambésy, CH, Switzerland conserve plant diversity and raise awareness of their threatened status (Müller et al. 2017). One of the aims of this Alpine Seed Conservation and Research Network (http://www. alpineseedconservation.eu/) is to safeguard 500 species of European alpine plants as seeds in ex situ collections based on their endemism, threat status, rarity, cultural and medicinal importance.

In addition to ex situ conservation the network also undertakes research to further the conservation of alpine plants in the face of climate change. One focus of this research is on Saxifraga, a common genus in the European Alps with 60 taxa found in diverse habitats and in diverse forms (Aeschimann et al. 2004). The research program is investigating the ecological behaviour of alpine Saxifraga and the impact of global warming on seed germination and longevity as well as seedling recruitment and establishment, involving both laboratory, common garden and field experiments. This has led to the collection and testing of more than twenty species of Saxifraga, together with an evaluation of the best storage methods for this material.

Saxifraga cernua L. is one of the 43 taxa of Saxifraga in Switzerland (species and subspecies, Lauber et al. 2007, Info Flora 2018). It has a wide circumpolar distribution across the High Arctic, but also occurs in more isolated populations in southern mountain ranges such as the European Alps (Hultén 
and Fries 1986). Across its distribution, S. cernua is threatened by climate change, and in some areas by habitat destruction, leading to protected status in several countries (e.g. UK, JNCC 2018).

A common feature of high-altitude plants is an increase in viviparous reproduction with elevation as a response to harsh environmental conditions (Körner 2003). For example, some species produce bulbils in place of seeds where the growing season is short (e.g. Pahl and Darroch 1997). This is the case for $S$. cernua, despite luxuriant flowering, seed set has only rarely been observed (Molau 1992; Brochmann and Håpnes 2001; Kapralov et al. 2006). The isolated peripheral populations of S. cernua in the European Alps show no signs of sexual reproduction (Bauert et al. 1998), instead reproducing via numerous bulbils produced in the stem leaf axils. Storing seeds is, therefore, not an option for ex situ conservation, necessitating investigation of the storage potential of bulbils of $S$. cernua, as there are, as far as we know, no other studies on this subject.

While the long-term conservation of orthodox seeds in seed banks has been shown to maintain longevity for $10 \mathrm{~s}$ to $100 \mathrm{~s}$ of years (Smith et al. 2003), the application of such storage conditions has shown mixed results for bulbils. Storage of seeds at the Royal Botanic Gardens, Kew's Millennium Seed Bank (MSB) involves the desiccation of seeds to $15 \%$ equilibrium relative humidity $(\mathrm{eRH})$, and cold storage at $-20{ }^{\circ} \mathrm{C}$ in hermetically sealed containers. The prevalence of short lived species at high altitude has been reported for the Italian Alps, and the need for alternative storage methods highlighted (Mondoni et al. 2011). Short lived species, whose viability can still deteriorate rapidly under these conditions (e.g. Salix spp.), have a portion of their seeds stored in liquid nitrogen in the vapor phase $\left(-180^{\circ} \mathrm{C}\right)$. For cryopreservation to be successful species-specific techniques need to be developed in relation to the species' natural freezing resistance, the explant size and type, and its water content (Pani et al. 2001). Ice crystallisation must be avoided during the freezing process, to prevent physical damage to the tissues - an issue that is more complex the larger the tissue being stored. It is likely, therefore, that for large bulbils excised material would be stored rather than the whole bulbil.

This study investigates the storage potential of $S$. сеrnua bulbils under both sets of storage conditions at the MSB. Drying has been shown to be a critical step in relation to bulbil storage, with some evidence that drying to $15 \%$ eRH kills bulbils (MSB, unpublished data). The effect of drying to a higher eRH on survival and cold storage was, therefore, also investigated.

\section{Methods}

Saxifraga cernua bulbils (Fig. 1) were collected in August 2016 at Bellalui (commune d'Icogne, Switzerland) at an altitude of 2200 m.a.s.l. (longitude and latitude $46^{\circ} \mathrm{N}$ and $\left.7^{\circ} \mathrm{E}\right)$. Approximately 3500 bulbils ( $0.75 \mathrm{~g}$ fresh weight) were harvested from 28 individuals. These were sent to the MSB for determination of their long-term storage potential under traditional seed banking methods.

The eRH of the collection was measured on arrival at the MSB and two germination tests of 50 bulbils each were set up on agar. The first was at $15{ }^{\circ} \mathrm{C}$, the second spent 8 weeks at $5{ }^{\circ} \mathrm{C}$ before being transferred to $15^{\circ} \mathrm{C}$. Both experienced 12/ 12 light regimes.

The remaining collection was split in half by weight. One half was dried to $15 \% \mathrm{eRH}$ at $15^{\circ} \mathrm{C}$, the other half was kept at $60 \%$ eRH at $20^{\circ} \mathrm{C}$. After 19 days, when the collections had equilibrated to their storage conditions, the original tests were replicated, creating four further germination tests.

Each collection from the different humidity conditions was then split and a portion of each was placed in conventional long-term storage in a hermetically sealed container at $-20{ }^{\circ} \mathrm{C}$ and a second portion was placed in cryopreservation storage at $-180{ }^{\circ} \mathrm{C}$ in vapor phase liquid nitrogen. After two months in storage germination tests were set up as before but only at $15^{\circ} \mathrm{C}$ as the two different sets of germination conditions had been found to give similar results in earlier tests.

All germination tests were scored for radicle emergence weekly under a microscope (Lynx stereo microscope) until no further germination occurred for four weeks. Cut tests were carried out on the remaining bulbils at the end of each test to assess the number that were moldy, empty or infested.

\section{Results}

The relative humidity of the bulbils on arrival at the MSB was $59.8 \%$ eRH at $20{ }^{\circ} \mathrm{C} 7$ days after collection.

The results of the initial germination tests indicate that the bulbils were alive on arrival at the MSB. The test at $15{ }^{\circ} \mathrm{C}$ achieved $72 \%$ germination, while that with 8 weeks at $5{ }^{\circ} \mathrm{C}$, then $15{ }^{\circ} \mathrm{C}$ achieved $100 \%$ germination (Table 1).

After 19 days of drying at $15 \%$ eRH and $15^{\circ} \mathrm{C}$, the germination test at $15{ }^{\circ} \mathrm{C}$ showed $92 \%$ germination, while the test receiving a cold treatment for 8 weeks showed $85 \%$ germination (Table 1). These results were slightly higher than the initial test and show that drying to $15 \%$ eRH at $15{ }^{\circ} \mathrm{C}$ had had no impact on the viability of the bulbils.

After 19 days of storage at $60 \% \mathrm{eRH}$ and $20{ }^{\circ} \mathrm{C}$, the germination test at $15{ }^{\circ} \mathrm{C}$ showed $90 \%$ germination, while the test receiving a cold treatment for 8 weeks showed $81 \%$ germination (Table 1). These figures are slightly lower than the initial test, but do not indicate a substantial loss of viability of the bulbils.

Interestingly, there is no marked variation in germination between the bulbils dried to $15 \%$ eRH and those stored at $60 \%$ eRH for the same period. There was also minimal difference 
Fig. 1 Saxifraga cernua bulbils
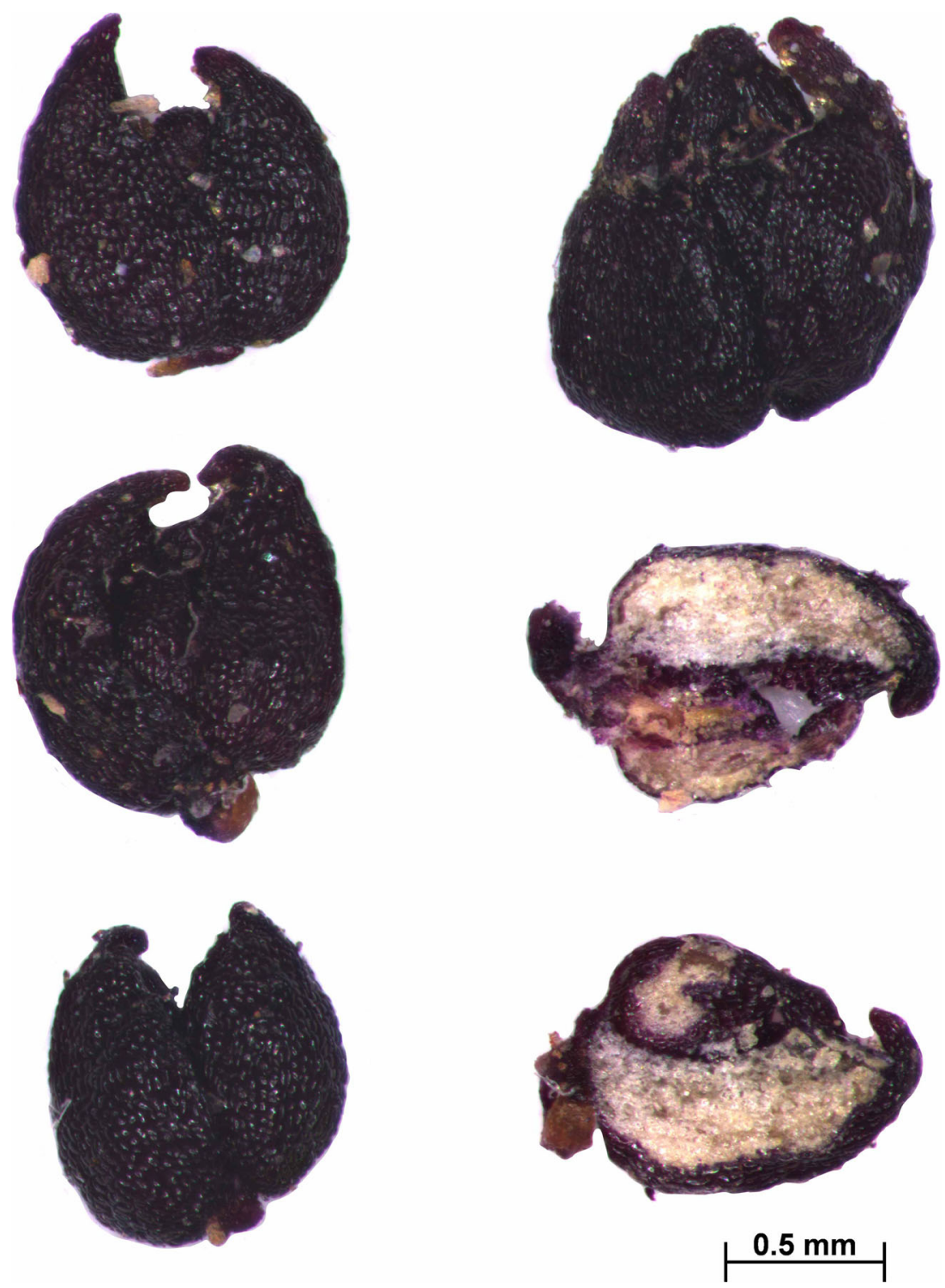

between the results of the two types of germination tests, although those held purely at $15^{\circ} \mathrm{C}$ showed higher germination. It was decided, therefore, that the remaining germination tests would only be run at $15^{\circ} \mathrm{C}$.

After cold storage for two months all samples showed high levels of germination ( $>76 \%$ ), with those dried to $15 \% \mathrm{eRH}$ fairing marginally better in cryopreservation $\left(-180{ }^{\circ} \mathrm{C}, 85 \%\right.$ germination), while those dried to $60 \% \mathrm{eRH}$ showed higher germination under traditional storage $\left(-20{ }^{\circ} \mathrm{C}, 83 \%\right.$ germination).

\section{Discussion}

Across its distribution, S. cernua is threatened by climate change, and in some areas by habitat destruction, leading to protected status in several countries (e.g. UK, JNCC 2018). An effective method of conserving vascular plant species is ex situ conservation in seed banks, this paper explored extending this conservation technique to bulbils of $S$. cernua.

In general, the viability of Saxifraga seeds declines rapidly in storage in traditional seed banks for orthodox seeds (Probert et al. 2009). We suggest that storage of bulbils offers a novel opportunity for the long-term conservation of this genus.

The high germination rate of fresh Saxifraga cernua L. bulbils in this study (72-100\%) confirms that this is an efficient means of recruitment for this species. Thus, bulbils may be useful at least for short-term ex situ storage, replacing seed storage for bulbiferous species with low or no seed production. It is interesting to note that the bulbils receiving a treatment of eight weeks at $5{ }^{\circ} \mathrm{C}$ had higher germination than the bulbils that did not receive this treatment. This could imply that cold stratification helps this species to germinate in the wild, as has been found for bulbils of Dioscorea (Chinese yam; Walck et al. 2010). 
Table 1 Germination test results for Saxifraga cernua L. bulbils

\begin{tabular}{|c|c|c|c|c|c|c|c|}
\hline \multirow{2}{*}{$\begin{array}{l}\text { Number of } \\
\text { bulbils }\end{array}$} & \multirow[t]{2}{*}{ eRH of bulbils (\%eRH) } & \multirow[t]{2}{*}{ storage temp $\left({ }^{\circ} \mathrm{C}\right)$} & \multirow{2}{*}{$\begin{array}{l}\text { Test conditions } \\
\text { (on agar) }\end{array}$} & \multicolumn{3}{|c|}{ Number of bulbils at end of test } & \multirow{2}{*}{$\begin{array}{l}\text { Percentage } \\
\text { germinatior }\end{array}$} \\
\hline & & & & Germinated & Mouldy & Empty & \\
\hline 50 & Fresh, $60 \%$ & 20 & $15^{\circ} \mathrm{C}$ & 28 & 11 & 11 & 72 \\
\hline 50 & Fresh, $60 \%$ & 20 & 8 weeks at $5^{\circ} \mathrm{C}$, then $15^{\circ} \mathrm{C}$ & 25 & 0 & 25 & 100 \\
\hline 50 & Stored at $15 \%$ & 15 & $15^{\circ} \mathrm{C}$ & 23 & 2 & 25 & 92 \\
\hline 52 & Stored at $15 \%$ & 15 & 8 weeks at $5^{\circ} \mathrm{C}$, then $15^{\circ} \mathrm{C}$ & 28 & 8 & 16 & 85 \\
\hline 50 & Stored at $60 \%$ & 20 & $15^{\circ} \mathrm{C}$ & 28 & 3 & 19 & 90 \\
\hline 51 & Stored at $60 \%$ & 20 & 8 weeks at $5^{\circ} \mathrm{C}$, then $15^{\circ} \mathrm{C}$ & 26 & 6 & 19 & 81 \\
\hline 30 & Stored at $15 \%$ & -20 & $15^{\circ} \mathrm{C}$ & 23 & 6 & 1 & 79 \\
\hline 44 & Stored at $15 \%$ & -180 & $15^{\circ} \mathrm{C}$ & 33 & 6 & 5 & 85 \\
\hline 36 & Stored at $60 \%$ & -20 & $15^{\circ} \mathrm{C}$ & 24 & 5 & 7 & 83 \\
\hline
\end{tabular}

Knowledge about the effects of germination and pregermination treatment of seeds (storage, desiccation tolerance, stratification) continue to improve (e.g. Baskin and Baskin 1998; Tweedle et al. 2003). Although the germination responses of various alpine species have been widely investigated with respect to temperature and desiccation tolerance (Eurola 1972; Molau and Prentice 1992; Müller et al. 2011; Alsos et al. 2013) the same is not true for bulbils. Proctor and Pence (2002) commented on this lack of knowledge highlighting the need for systematic studies to determine which "are truly desiccationtolerant and which are simply highly resistant to water loss."

To avoid desiccation damage the water content must be maintained above a critical level (Ballesteros and Walters 2007). This study found the bulbils of $S$. cernua to be desiccation tolerant, with no impact of drying to $15 \% \mathrm{eRH}$ on germination results compared with bulbils held at $60 \%$ eRH. This implies that the hydration window for $S$. cernua is relatively wide. Having established that the bulbils could survive the drying process the second step of traditional seed banking was then investigated, namely cold storage. This was carried out by the two traditional methods in seed banking, at $-20{ }^{\circ} \mathrm{C}$ and at $-180^{\circ} \mathrm{C}$ (vapor phase liquid nitrogen - cryopreservation).

No substantial impact on germination results was found between either cold storage temperature at either eRH. Further study is required to determine the long-term impact of storage at different eRH on viability. Seeds held at higher humidity lose their viability more rapidly than those stored at lower eRH, and thus survive for shorter periods in ex situ storage (Probert 2003). Further investigation is required to identify the critical water content for these bulbils to avoid both desiccation and freezing damage.

These results show that bulbils of $S$. cernua can be stored under traditional seed bank conditions to help conserve this species. This is of particular relevance for S. cernua, as in contrast to the situation of arctic populations of this species (Gabrielson and Brochmann 1998; Kjølner et al. 2004), isolated relict populations in the Alps show a lack of genetic variation (Bauert et al. 1998). This suggests that it is unnecessary to sample each population of the Alps in order to make a representative ex situ conservation collection. In our case, the small size of the populations sensu Ellstrand and Elam (1993), is not necessarily a problem in relation to conservation, as long as the population collected from is healthy.

This study provides hope for the long-term ex situ conservation of species with low or no seed set that produce small sized bulbils that can then be treated in the same manner as orthodox seeds. This opens up new avenues of conservation for high altitude and high latitude plants using viviparous reproduction. Further work is underway to see if these results are translatable to other bulbil producing species in the Alps.

Acknowledgments We would like to thank Winton Philanthropies for making this work possible through their generous funding of the European Alpine Seed Conservation and Research Network.

Funding Funding was provided to the Royal Botanic Gardens, Kew by Winton Philanthropies. This took the form of a philanthropic donation, there is no grant number.

\section{Compliance with ethical standards}

Conflict of interest The authors declare that they have no conflict of interest.

Ethical approval Ethical standards were adhered to in this study and in the production of this manuscript.

Informed consent No human participants were involved in this study.

Open Access This article is distributed under the terms of the Creative Commons Attribution 4.0 International License (http:// creativecommons.org/licenses/by/4.0/), which permits unrestricted use, distribution, and reproduction in any medium, provided you give appropriate credit to the original author(s) and the source, provide a link to the Creative Commons license, and indicate if changes were made. 


\section{References}

Aeschimann D, Lauber K, Moser DM (2004) Flora alpina. Ein Atlas sämtlicher Gefässpflanzen der Alpen. Haupt Verlag, Bern

Aeschimann D, Rasolofo N, Theurillat JP (2011) Analyse de la flore des Alpes. 1: historique et biodiversité. Candollea 66:27-55. https://doi. org/10.15553/c2011v661a2

Alsos IG, Müller E, Eidesen PB (2013) Germinating seeds or bulbils in 87 of 113 tested Arctic species indicate potential for ex situ seed bank storage. Polar Biol 36:819-830. https://doi.org/10.1007/ s00300-013-1307-7

Ballesteros D, Walters C (2007) Calorimetric properties of water and triacylglycerols in fern spores relating to storage at cryogenic temperatures. Cryobiology 55:1-9. https://doi.org/10.1016/j.cryobiol. 2007.03.006

Baskin CC, Baskin JM (1998) Seeds: ecology, biogeography, and evolution of dormancy and germination. Academic Press, San Diego

Bauert MR, Kälin M, Baltisberger M, Edwards JP (1998) No genetic variation detected within isolated relict populations of Saxifraga cernua in the Alps using RAPD markers. Mol Ecol 7:1519-1527. https://doi.org/10.1046/j.1365-294x.1998.00470.x

Brochmann C, Håpnes A (2001) Reproductive strategies in some arctic Saxifraga (Saxifragaceae), with emphasis on the narrow endemic S. svalbardensis and its parental species. Bot J Linn Soc 137:31-49. https://doi.org/10.1111/j.1095-8339.2001.tb01103.x

Ellstrand NC, Elam DR (1993) Population genetic consequences of small population size: implications for plant conservation. Annu Rev Ecol Evol Syst 24:217-242. https://doi.org/10.1146/annurev.es.24. 110193.001245

Eurola S (1972) Germination of seeds collected in Spitsbergen. Ann Bot Fenn 31:149-159

Gabrielson TM, Brochmann C (1998) Sex after all: high level of diversity detected in the arctic clonal plant Saxifraga cernua using RAPD markers. Mol Ecol 7:1701-1708. https://doi.org/10.1046/j.1365294x.1998.00503.x

Gottfried M, Pauli H, Futschik A, Akhalkatsi M, Barančok P, Benito Alonso JL, Coldea G, Dick J, Erschbamer B, Fernández Calzado MR, Kazakis G, Krajči J, Larsson P, Mallaun M, Michelsen O, Moiseev D, Moiseev P, Molau U, Merzouki A, Nagy L, Nakhutsrishvili G, Pedersen B, Pelino G, Puscas M, Rossi G, Stanisci A, Theurillat JP, Tomaselli M, Villar L, Vittoz P, Vogiatzakis I, Grabherr G (2012) Continent-wide response of mountain vegetation to climate change. Nat Clim Chang 2:111-115. https://doi.org/10.1038/nclimate1329

Hultén E, Fries M (1986) Atlas of north European vascular plants (north of the tropic of cancer) Vols. I-III. Koeltz Scientific Books, Königstein

Info Flora (2018) Info Flora, Switzerland. Available from https://www. infoflora.ch/en/flora/saxifraga.html. Accessed September 2018

JNCC (Joint Nature Conservation Committee) (2018) Guidance on contents and use of the conservation designations spreadsheet. Available from http://jncc.defra.gov.uk/page-3418. Accessed September 2018

Kapralov MV, Gabrielsen TM, Sarapultsev IE, Brochmann C (2006) Genetic enrichment of the arctic clonal plant Saxifraga cernua at its southern periphery via the alpine sexual Saxifraga sibirica. Mol Ecol 15:3401-3411. https://doi.org/10.1111/j.1365-294X.2006. 03024.x

Kjølner S, Såstad SM, Taberlet P, Brochmann C (2004) Amplified fragment length polymorphism versus random amplified polymorphic
DNA markers: clonal diversity in Saxifraga cernua. Mol Ecol 13: 81-86. https://doi.org/10.1046/j.1365-294X.2003.02037.x

Körner C (2003) Alpine plant life, functional plant ecology of high mountain ecosystems, 2nd edn. Springer-Verlag, Berlin Heidelberg

Lauber K, Wagner G, Gygax A (2007) Flora Helvetica. 4ème éd. Haupt Verlag, Germany

Molau U (1992) On the occurrence of sexual reproduction in Saxifraga cernua and S. foliolosa (Saxifragaceae). Nord J Bot 12:197-203. https://doi.org/10.1111/j.1756-1051.1992.tb01290.x

Molau U, Prentice HC (1992) Reproductive system and population structure in three arctic Saxifraga species. J Ecol 80:149-161

Mondoni A, Probert RJ, Rossi G, Vegini E, Hay FR (2011) Seeds of alpine plants are short lived: implications for long-term conservation. Ann Bot 107(1):171-179. https://doi.org/10.1093/aob/mcq222

Müller E, Cooper EJ, Alsos G (2011) Germinability of arctic plants is high in perceived optimal conditions but low in the field. Botany 89: 337-348. https://doi.org/10.1139/b11-022

Müller JV, Berg C, Détraz-Méroz J, Erschbamer B, Fort N, LambeletHaueter C, Margreiter V, Mombrial F, Mondoni A, Pagitz K, Porro F, Rossi G, Schwager P, Breman E (2017) The alpine seed conservation and research network - a new initiative to conserve valuable plant species in the European Alps. J Mt Sci 14(4):806-810. https:// doi.org/10.1007/s11629-016-4313-8

Pahl M, Darroch B (1997) The effect of temperature and photoperiod on primary floral induction in three lines of alpine bluegrass. Can J Plant Sci 77:615-622. https://doi.org/10.4141/P96-108

Pani B, Swennen R, Engelmann F (2001) Cryopreservation of plant germplasm. Acta Hortic 560:79-86

Pauli H, Gottfried M, Dullinger S, Abdaladze O, Akhalkatsi M, Benito Alonso JL, Coldea G, Dick J, Erschbamer B, Fernández Calzado R, Ghosn D, Holten JI, Kanka R, Kazakis G, Kollár J, Larsson P, Moiseev P, Moiseev D, Molau U, Molero Mesa J, Nagy L, Pelino G, Pușcaș M, Rossi G, Stanisci A, Syverhuset AO, Theurillat JP, Tomaselli M, Unterluggauer P, Villar L, Vittoz P, Grabherr G (2012) Recent plant diversity changes on Europe's mountain summits. Science 336:353-355. https://doi.org/10.1126/science.1219033

Probert RJ (2003) Seed viability under ambient conditions and the importance of drying. In: Smith RD, Dickie JB, Linington SH, Pritchard HW, Probert RJ (eds) Seed conservation: turning science into practice. Royal Botanic Gardens Kew, UK, pp 337-365

Probert RJ, Daws MI, Hay FR (2009) Ecological correlates of ex situ seed longevity: a comparative study on 195 species. Ann Bot 104:57-69. https://doi.org/10.1093/aob/mcp082

Proctor MCF, Pence VC (2002) Vegetative tissues: bryophytes, vascular resurrection plants and vegetative propagules. In: Black M, Pritchard HE (eds) Desiccation and Plant Survival: Drying Without Dying. CABI Publishing, Wallingford, pp 207-238

Smith RD, Dickie JB, Linnington SH, Pritchard HW, Probert RJ (2003) Seed conservation, turning science into practice. Royal Botanic Gardens Kew, UK

Tweedle JC, Dickie JB, Baskin CC, Baskin JM (2003) Ecological aspects of seed desiccation sensitivity. J Ecol 91(2):294-304. https://doi.org/ 10.1046/j.1365-2745.2003.00760.x

Walck JL, Cofer MS, Hidayati SN (2010) Understanding the germination of bulbils from an ecological perspective: a case study on Chinese yam (Dioscorea polystachya). Ann Bot 106(6):945-955. https://doi. org/10.1093/aob/mcq189

Publisher's note Springer Nature remains neutral with regard to jurisdictional claims in published maps and institutional affiliations. 